\begin{tabular}{c} 
Volume and Issues Obtainable at Center for Sustainability Research and Consultancy \\
www.globalcsrc.org \\
Journal of Business and Social Review in Emerging Economies \\
ISSN: 2519-089X; (Online) 2519-0326 \\
Volume 2: Issue 1 June 2016 \\
$\begin{array}{c}\text { CSRᄃ } \\
\text { Profit }\end{array}$ \\
\hline
\end{tabular}

\title{
The Influence of Extrinsic Motivation on Innovative Work Behaviour with Moderating Role of Quality Culture
}

\author{
${ }^{1 *}$ Tahir Noaman Abdullatif, ${ }^{2}$ Husna bt Johari, ${ }^{3}$ Zurina bt Adnan \\ ${ }^{1} \mathrm{PhD}$ Scholar, College of Business, Universiti Utara Malaysia, tahiralbaditemr@yahoo.com \\ ${ }^{2}$ Assistant Professor, College of Business, Universiti Utara Malaysia, husna@uum.edu.my \\ ${ }^{3}$ Lecturer, College of Business, Universiti Utara Malaysia, rina@uum.edu.my
}

\begin{tabular}{l}
\hline ARTICLE DETAILS \\
\hline History \\
Revised format: May 2016 \\
Available Online: June 2016 \\
\\
\hline Keywords: \\
Innovative Work Behaviour \\
Extrinsic Motivation \\
Quality Culture \\
Higher Education
\end{tabular}

JEL Classification:

O31,O39,M19

\begin{abstract}
Objective: This study explored the influence of extrinsic motivation on innovative work behaviour in higher education institutions in Iraq as moderated by quality culture. Although the employees' innovative work behaviour is the key sources of organizational innovation, it does not develop automatically. Leadership should give employees suitable work incentives and more motivation to increase their innovative behaviour.

Methodology:This study discusses the theoretical concepts based on Social Exchange Theory and previous studies to explore the logical relationships between research variables.

The results: The research study concludes that the feeling of extrinsic motivation is enormously important to realize the continuous flow of innovative work behavior, especially through the influence of quality culture on this relationship. Likewise, in line with the Social Exchange Theory, extrinsic motivation may positively influence innovative work behaviour. In addition, the quality culture, as one of the contextual factors, is very important for the higher education institutions as it affects the innovative work behaviour of employees.

Implication: The results are expected to have both theoretical and practical contributions to enable Iraqi higher education institutions to improve the level of innovation.. The results of this study can be used as a strategy by the administration for the purpose of improving innovative work behaviour. This study involves several limitations, including the lack of empirical examination. The future empirical studies may use this theoretical framework to cover this aspect.
\end{abstract}

(C) 2016 The authors, under a Creative Commons AttributionNonCommercial 4.0

\section{Introduction}

There has been increasing interest of researchers in the area of innovation due to the changes in the environment and challenges confronted by organizations (Jabbour, Neto, Gobbo, Ribeiro, \& Jabbour, 2015; Shahin \& Zeinali, 2010). Innovation is a tool for economic growth as it creates competitive

*Corresponding author's email address: tahiralbaditemr@yahoo.com

Recommended citation: Abdullatif, N. T. Johari, H. Haalib, M. (2016). The Influence of Extrinsic Motivation on Innovative Work Behaviour With Moderating Role of Quality Culture. Journal of Business and Social Review in Emerging Economies, 2 (1) 79-86. DOI: https://doi.org/10.26710/jbsee.v2i1.21 
opportunities for achieving profit and attaining benefits for the organization (Erturk, 2012). In addition, Amabile et al (1996) confirmed that in the current times, the organization's success depends on the intelligence and innovation of the staff more than the traditional tangible resources. In this background, it is found that innovation is connected with innovative work behavior (IWB), which is the generation, promotion and implementation of new ideas (Kumar, 2012).

In the context of Iraq, the country is known for its 8,000 years of recorded history and its leading position among Arab states in the caliber of its social programs and education (Mahmud, 2013). In the previous decades, the level of HE in Iraq had been progressive and developed and this made it superior to states in the Middle East and the Arab Gulf (Al-Husseini, 2014). However, due to wars and UN sanction, the Iraqi higher education (HE) is presently suffering from significantly reduced research, educational activity, and innovation studies.Therefore, intensive surveys are involved in this field in order to enhance the quality of teaching, research and development capabilities and the innovation of the academic staff (Al-Husseini, 2014). Given the importance of innovative work behavior in the HE sector, mainly learning environments like universities, it is significant to improve and boost the innovation within them. Likewise, it is possible to raise the degree of knowledge relating to the courses of pedagogy and to improve the employees capabilities of organization problem-solving (Al-Husseini, 2014). More importantly, improving the quality of HE is expected to lead to the growth of the Iraqi nation (Faylee, 2013).

According to laboratory research and modern theories, increase in extrinsic motivation may result in individual perceptions of their own behaviour (Cho \& Perry, 2012). In addition, the Social Exchange Theory posits that extrinsic motivation may positively influence innovative work behaviour (Blau, 1964). Along a similar line of argument, Thomas, (2002) pointed out that extrinsic motivation (reward, payment, and profit) have a vast influence on the encouragement of employees to exert their efforts towards generating new ideas, then implementing them within the organization. According to the recommendation by Naranjo, Jiménez and Valle (2011), future studies have to focus on the moderating effect of cultivation between the relationship of various variables and innovation. In this regard, character growth in organizations is focused on motivating the quality culture that facilitates individual performance and innovation to constantly improve their professional lifetimes. Although this understanding of the quality culture as part of the organizational culture is gaining more importance, there is still lack of basic research and theoretical understanding of the phenomenon itself (Ehlers, 2009).

Prior researchers confirmed the importance of quality culture in raising the level of quality in the organization (e.g., Jinhui, Zhang \& Schroeder, 2011). Growth and development of quality culture, and its application in institutions within the organizational contexts, as part of the overall culture of the organization, has not yet developed a strong tradition in research and theory (Ehlers, 2009). Through the literature review, it was found that organizational factors, such as quality culture, are important variables for innovative work behaviour (Xerri, Brunetto \& Shacklock, 2009). In this regard, there is lack of studies that tested quality culture in literature as the moderating variable between extrinsic motivation and innovative work behaviour in Iraqi HE. Therefore, this study aims to investigate the relationship between extrinsic motivation and innovative work behaviour as moderated by quality culture in Iraqi HE.

\section{Literature Review}




\subsection{Innovative Work Behaviour}

In the past few years, there has been a notable change in the different business sectors all over the globe. It has also bee noted, that it is essential for organizations, firms and institutions to come up with creative solutions for successful performance (Agarwal, 2014). It is crucial for organizations to adopt continuous innovation in their operations in terms of their products and internal processes. Therefore, among the significant aspects in this regard is to leverage the abilities and capabilities of staff for the development of innovation (Gupta, Guha \& Krishnaswami, 2013). The creativity of the employee is a source of new ideas that may be applicable to the team or the whole organization and is crucial for the organizational survival and maintenance (Agarwal, 2014). More specifically, innovative work behavior (IWB) refers to a process that generates a change in terms of products, processes or procedures that are novel to the firm (Sapie, Hussain, Awang \& Ishak, 2015). Moreover, innovative work behaviour (IWB) was defined by Damanpour (1991) as the production, growth and employment of new thoughts/behaviour that could take the form of a novel product/service, construction or system of management, and new work program for organizational members (Sapie et al., 2015). Meanwhile, Farr and Ford (1990) referred to the concept as thebehaviour of an individual that achieves the beginning and voluntary generation of new and invaluable ideas, methods, products, and processes. Nevertheless, the IWB concept is relatively new, and visions of creativity have been often used in literature to develop assumptions about relations with IWB (De Spiegelaere, 2014).

The majority of studies in literature stressed on the creativity of employees, particularly on the early innovation process steps. Several authors have argued for the expansion of the construct and to view the ideas application in a more scientific way (e.g. Rajaei, Jalili, Abadi, \& Azizkhani, 2015).Additionally, De Jong and Hartgog (2008) stated that the innovative work behaviour is aligned with idea generation, and requires behaviours to conduct ideas that ultimately achieves improved business performance (Dzulkifli \& Md Noor, 2012). Therefore, innovative work behaviour is an important factor for both private and public business sectors (Al-Hasany, 2014). In the public sector, innovation is particularly important in the HE sector, where the encouragement of individuals is a must to develop and diffuse innovation (Borins, 2001).

\subsection{Extrinsic Motivation}

Extrinsic motivation refers to our propensity to carry out activities in lieu of external rewards, whether they be physical (money) or psychological or mental (praise) in nature (Brown, 2007). Performancebased incentives are employed in the majority of countries, particularly in the public sector as supported by laws mandated for organizations concerning remuneration (Demir, 2011). Therefore, the incentives are externally provided in that, it is due to the employees notwithstanding their work (Cho \& Perry, 2012). Although the effect of such incentives is less than that of intrinsic motivation (Deci \& Ryan, 2004), their probability of positively impacting employee behaviour exists. According to laboratory research and modern theories, the increase in extrinsic motivation may result in individual perceptions of their own behaviour (Cho \& Perry, 2012), where such reward motivations comprise of financial rewards (Antikainen, Makipaa \& Ahonen, 2010), free goods as well as free services (Anderson, 2009). Economic motivation is of a different type, consisting mainly of intellectual property right sharing (e.g. Avenali, Battistella, Matteucci \& Nonino, 2013). Extrinsic motivation may predict a positive or negative influence on innovative behaviour (Nezhad, Akbari \& Ramezani, 2015). On the basis of the discussed literature, the challenging elements of work motivation are correlated with the notion of the generation of innovative behaviour (Rezaie, 2014). Motivation can enhance the innovation work behaviour via maximized autonomy and competence of workers (Yidong \& Xinxin, 2013). 


\subsection{Quality Culture}

Quality Culture is the collection of norms, values, concepts, beliefs, behavior and rules, shared by individuals and groups in an organization, which are related to the importance of to its quality (Detert, Schroeder \& Mauriel, 2000). This is one of the justifications of why quality direction has turned to employee behaviour and business practice for more enlightening findings (Campos, Mendes, Silva \& Valle, 2014; Wang, Chen, \& Chen, 2012). Researchers are of the consensus that quality can be employed as a source of benefit in the business environment, wherein innovation, knowledge development, demanding consumers and technology all have key contributions (Gretzel, Fesenmaier \& O'Leary, 2006). In the final years of the 20th century, studies concerning quality were focused on discovering new conceptualizations that had the potential to provide insight into the dimensions of analysis that were largely ignored prior to that period (Barrett \& Waddell, 2001).

According to Kujala and Lillrank (2004), from the perspective of culture, quality is described as a subsystem of the organization. Similarly, Cameron and Sine (1999) explained that culture is unique based on its beliefs, practices, and values, where the values are ongoing aims that help in guiding people's lives and are described as indicated or implied formalizations of the distinct culture that influences the individual's actions. Contrastingly, practices refer to methods and behaviours that are observed in the institute (Asreen, Zain \& Razalli, 2010) and lastly, beliefs refer to the shared assumptions why individuals in the firm feel about their environment and how they are directed towards the course of action in certain circumstances (Kujala \& Lillrank, 2004).

In this line of study, the most significant is one that was carried out by Mintzberg (1994). His study confirmed that changes in the organizations stem from the competencies of staff and the culture of the organization. In order to comprehend the quality management aspects, its tools, capabilities, and values of both employees and organization, they should not be studied separately but as a comprehensive whole. One of the critical success components in the education sector is its academic staff, and this makes a difference in a country attempting to develop and improve educational quality (Arifin, Troena \& Djumahir, 2014).

\section{Discussion}

\subsection{Extrinsic Motivation and Innovation Work Behaviour}

Extrinsic motivation in the form of financial motivation and appreciation, helps to bring about creativity and innovation (Van Dijk \& Van den Ende, 2002). In regards to the creativity and innovation perspective in firms, creativity displayed by employees have to be recognized and rewarded (Amabile, 1988; Amabile et al., 1996). Therefore, the major activities for managing creativity and innovation in firms involve the management of the employees' attention (Van de Ven, 1986) to a degree that they are made aware that creative behaviour is acknowledged and rewarded (via increases in pay, advancements or promotion). In other words, according to Scott and Bruce (1994), innovative behaviour is deemed to be a salient objective for the employees in such a way that they will be inclined towards innovation.

Nevertheless, rewards should not be viewed as something that is a right or contracted, as opposed to a privilege based on the competence and creative activities of employees, as the former may work to minimize their interest in their work (Amabile, et al., 1996; Amabile, Hennessey \& Grossman, 1986). Thus, general rewards like raises in pay/promotions for innovative behavior are encouraged over 
rewards that relate to ongoing activities owing to the the first type's potential to be viewed as the acknowledgment for creative achievements and not as controlling mechanisms (George \& Zhou, 2002).Therefore, based on the aforementioned, there is a need to use motivation sources and environment resource or contextual factors to enhance and improve innovative work behavior among academic staff in HE in Iraq. In the context of the present study, extrinsic motivation is considered to be the independent variable and innovative work behavior as the dependent variable, while quality culture is the moderating variable.

\subsection{Quality Culture as a Moderator between Extrinsic Motivation and Innovative Work Behavior}

There are several managerial, psychological and other disciplinary concepts that depend on moderating variables, particularly those that impact the relationship strength/nature or both of two variables. Although such effects are significant, the testing and analysis methods are not well clarified. Generally speaking, a moderator is described as a variable that impacts the relationship between two or more variables, and moderation is the impact of the moderator on such a relationship (Dawson, 2014). In regards to this, quality culture is considered to be a part of the culture in the organization that contributes to bringing about innovation behavior (Amabile et al., 1996; Hemlin, Allwood \& Martin, 2008; PirolaMerlo, Bain \& Mann, 2005; Woodman, Sawyer \& Griffin, 1993).In addition,individuals who perceive support are more inclined to examine novel ideas and methods to achieve their goals and tasks or to solve the on-the-job problems (Pirola-Merlo et al., 2005).

Furthermore, Kausar (2014) defined organizational culture as a system of concerns, shared values, norms and common beliefs that are extensively acknowledged and shared among the employees. According to the organization theory, culture affects the beliefs of employees continuously and it indirectly affects the organizational practices (Nahm, Vonderembse \& Koufteros, 2004). Quality culture is, on the other hand, the pattern of beliefs, and behavior in light of quality. In order to achieve quality, the company goals require a positive quality culture to support it. A quality culture needs clear values and beliefs, as this would bring about total quality behavior (Linklow, 1989). It therefore comes to reason that organizations that are desirous of managing quality programs within their organization need to focus on the development of an appropriate quality culture (Dellana \& Hauser, 1999). However, the concept of quality culture has not been thoroughly examined in literature (Mahmood,Mohammed, Misnan, Yusof \& Bakri, 2006). According to McCleland (1975), leaders who are aware of the quality culture assist employees to recognize problems quickly, and access the necessary resources easily through concerted efforts, which are supported by the cooperative organizations (Kitapci, Okten \& Süleyman, 2009). Extrinsic motivation and quality culture may support the leaders to stimulate employees to discover the innovative solutions to the problems at work (Kitapci, et al, 2009). Nevertheless, quality culture of $\mathrm{HE}$ in Iraq has not received sufficient attention from research or literature, although researchers confirmed the importance of quality culture in raising the level of quality in the organization (Jinhui, et al., 2011). To the researcher's best knowledge, this variable has not been used as a moderator in the study of innovative work behavior.

\section{Conclusion}

Motivation is the key through which individuals can customize efforts to generate and implement innovative thoughts. In relation to this, personnel is encouraged to move beyond their designated role and engage in spontaneous and innovative activities, particularly if they display a strong identity with the goals and mission of the organization. Many researchers have revealed that innovation needs to be supported and encouraged in the organization and in line with this, when individuals working in the organization are supported, they feel they can test new ideas and methods aimed at achieving their goals or completing their tasks. Moreover, quality culture has a vital role in stimulating creative behavior among employees to build obligations towards their institution. In relation to innovation, while 
innovation contributes value to the organization, quality culture accepts the norms relating to prevailing innovation in the organization. As a result, this culture stimulates new innovative solutions and improvements in the organization and provides direct feedback, and communication channels to facilitate tacit knowledge. It also allows for independent work of the mission in order to seek more innovation. Finally, the use of rewards and incentive system with the help of quality culture will definitely encourage the Iraqi HE staff to work hard, and ultimately, achieve good quality and enhanced innovation.This study suggests future research to test this model empirically and explore different variables (individual or contextual) and their relationships with innovative work behaviour in many sectors and in different countries.

\section{References}

Agarwal, U. A. (2014). Linking justice, trust and innovative work behaviour to work engagement. Personnel Review, 43(1), 41-73.

Al-Husseini, S. J. (2014). The impact of leadership style on innovation in Iraq's higher education institutions: the role of knowledge sharing.( Doctoral dissertation, University of Plymouth).

Amabile, T. M. (1988). A model of creativity and innovation in organizations. In B. M. Staw, \& L. L. Cummings (Eds.), Research in organizational behavior, 10(1) pp. 187-209).

Amabile, T. M., Conti, R., Coon, H., Lazenby, J., \& Herron, M. (1996), 'Assessing the work environment for creativity', Academy of Management Journal, 39(5) 1154-1184.

Amabile, T. M., Hennessey, B. A., \& Grossman, B. S. (1986). Social influences on creativity: The effects ofcontracted-for reward. Journal of Personality and Social Psychology, 50 (1)14-23.

Anderson, J. (2009). Free: The future of a radical price. New York, NY: Hyperion.

Antikainen, M., Mäkipää, M., \& Ahonen, M. (2010). Motivating and supporting collaboration in open innovation. European Journal of Innovation Management, 13(1), 100-119.

Arifin, F., Troena, E. A., \& Djumahir, M. R. (2014). Organizational Culture, Transformational Leadership, Work Engagement and Teacher's Performance: Test of a Model. International Journal of Education and Research.2(1),1-14

Asree, S., Zain, M., \& Rizal Razalli, M. (2010). Influence of leadership competency and organizational culture on responsiveness and performance of firms. International Journal of Contemporary Hospitality Management, 22(4), 500-516.

Avenali, A., Battistella, C., Matteucci, G., \& Nonino, F. (2013). A mechanism for supporting collective innovation: the open contract-based challenge. Information Systems and e-Business Management, 11(4), 541-568.

Barrett, B. \& Waddell, D. (2001). Quality culture and its impact on quality performance. The 5th International and 8th National Research Conference on Quality and Innovation Management 12-14 Feb. 2001, The Euro-Australian Cooperation Centre, Victoria, 1-11.

Blau, P. (1964). Exchange and power in social life. New York: Wiley \& Sons.

Borins, S. (2001). Encouraging innovation in the public sector. Journal of intellectual capital, 2(3), 310319.

Brown. (2007). Psychology of Motivation. Hauppauge NY: Nova Science Publishers Inc.

Cameron, K. \& Sine, W. (1999). A framework for organisational quality culture. Quality Management Journal, 6(4), 7-25.

Campos, A. C., da Costa Mendes, J., Silva, J. A., \& do Valle, P. O. (2014). Critical success factors for a total quality culture: A structural model. Tourism \& Management Studies, 10(1), 7-15.

Cho, Y. J., \& Perry, J. L. (2012). Intrinsic motivation and employee attitudes role of managerial trustworthiness, goal directedness, and extrinsic reward expectancy. Review of Public Personnel Administration, 32(4), 382-406..

Damanpour, F. (1991). Organizational innovation: A meta-analysis of effects of determinants and moderators. Academy of management journal, 34(3), 555-590. 
Dawson, J. F. (2014). Moderation in management research: What, why, when, and how. Journal of Business and Psychology, 29(1), 1-19.

De Jong, J. P. J., \& Den Hartog, D. N. (2008). Innovative work behavior: Measurement and validation. EIM Business and Policy Research. Working paper. The Netherlands, University of Amsterdam. Amsterdam Business School.

De Spiegelaere, S. (2014). The Employment Relationship and Innovative Work Behaviour. status: published.

Deci, E. L., \& Ryan, R. M. (2004). Handbook of self-determination research. Rochester, NY: University of Rochester Press.

Dellana, S.A. and R.D. Hauser, 1999. Towards defining quality culture, Engineering Management Journal, 11(2): 11-15.

Demir, K. (2011). Teachers'intrinsic And Extrinsic Motivation As Predictors Of Student Engagement: An Application Of Self-Determination Theory. Nwsa: Education Sciences, 6(2), 1397-1409.

Detert, J. R., Schroeder, R. G., \& Mauriel, J. J. (2000). A framework for linking culture and improvement initiatives in organizations. Academy of management Review, 25(4), 850-863.

Dzulkifli, B. A., \& Md Noor, H. (2012). Assessing the organizational climate towards developing innovative work behavior: A literature review. 3rd International Conference On Business And Economic Research \( 3rd Icber 2012 \) Proceeding 12 - 13 March 2012. Golden Flower Hotel, Bandung, Indonesia.

Ehlers, U. D. (2009). Understanding quality culture. Quality Assurance in Education, 17(4), 343-363.

Erturk, A. (2012). Linking psychological empowerment to innovation capability: Investigating the moderating effect of supervisory trust. International Journal of Business and Social Science, 3(14), 153-165.

Farr, J. L., \& Ford, C. M. (1990). Individual innovation. In M. A. West \& J. L. Farr (Eds.), Innovation and creativity at work: Psychological and organizational strategies (pp. 63-80). Chichester: John Wiley.

Faylee, Z. (2013). Improving the Higher Education Sector in Iraq through Student Collaborations. Kufa Review ( 2(مجلةالكوفة 3 ).

George, J. M., \& Zhou, J. (2002). Understanding when bad moods foster creativity and good ones don't: the role of context and clarity of feelings. Journal of Applied Psychology, 87 (4), 687.

Gretzel, U., Fesenmaier, D. R. \& O`Leary, J. T. (2006). The transformation of consumer behavior. In: D. Buhalis \& C. Costa (Ed.), Tourism Business Frontiers (Consumers, Products and Industry) (pp. 9-18). Burlington: Butterworth-Heinemann.

Gupta, P. D., Guha, S., \& Krishnaswami, S. S. (2013). Firm growth and its determinants. Journal of Innovation and Entrepreneurship, 2(1), 1-14.

Hemlin, S., Allwood, C. M., \& Martin, B. R. (2008). Creative knowledge environments. Creativity Research Journal, 20(2) 196-210.

Jabbour, C. J. C., Neto, A. S., Gobbo, J. A., de Souza Ribeiro, M., \& de Sousa Jabbour, A. B. L. (2015). Eco-innovations in more sustainable supply chains for a low carbon economy: A multiple case study of human critical success factors in Brazilian leading companies. International Journal of Production Economics, 164, 245-257.

Jinhui Wu, S., Zhang, D., \& Schroeder, R. G. (2011). Customization of quality practices: the impact of quality culture. International Journal of Quality \& Reliability Management, 28(3), 263-279.

Kausar, (2014). Impact of Quality Culture on Employees' Motivation: A Study on Education Sector of Pakistan. Middle-East Journal of Scientific Research, 22(7), 1082-1089.

Kitapci, Hakan Ökten, Sultan Süleyman.( 2009). The impact of empowerment and quality culture on job satisfaction. Journal of Global Strategic Management.6(9)171-180.

Kujala, J. \& Lillrank, P. (2004). Total Quality Management as a cultural phenomenon. Quality Management Journal, 11(4), 43-55. 
Kumar, S. (2012). Kac-Moody groups, their flag varieties and representation theory (Vol. 204). Springer Science \& Business Media.

Linklow, P. (1989). Is Your Culture Ready For Total Quality? Quality Progress, 22(11), 69-71.

Mahmud, S. F. (2013). The Higher Education in Iraq Challenges And Recommendations. Journal of Advanced Social Research l, 3(9), 255-264.

Mahmood, W.Y., Abdul Hakim Mohammed, A., Misnan, M.S., Yusof, Z.M. \& Bakri, B. (2006). Development of Quality Culture in the Construction Industry. ICCI, 2006. Universiti Teknologi, Malaysia, UTM, Skudai, 81310, Johor, Malaysia.

McClelland, D. C. (1975). Power: The inner experience. New York: Irvington.

Mintzberg, H. (1994). The Rise and Fall of Strategic Planning. Hemel Hempstead.

Nahm, A.Y., Vonderembse, M.A. and Koufteros, X.A. (2004), - The impact of organizational culture on time-based manufacturing and performance”, Decision Sciences, 35 ( 4) 579-607.

Naranjo-Valencia, J. C., Jiménez-Jiménez, D., \& Sanz-Valle, R. (2011). Innovation or imitation? The role of organizational culture. Management Decision, 49(1), 55-72.

Nezhad, F., Z, G., Alkbari, A., \&Ramezani, S. (2015). Employee‘s Personality Traits, Work Motivation and Innovative Behavior, GMP Review, 17(1) 311-321.

Pirola-Merlo, A., Bain, P. G., \& Mann, L. (2005). The impact of team climate on innovation in $R \& D$ teams. Leadership, Management, and Innovation in $R \& D$ Project Teams.

Rajaei, Y., Jalili, M., Abadi, N. N. S., \& Azizkhani, H. (2015). Study effects of leadership styles on creativity behavior of stuffs (Case study: welfare organization of Abhar city).

Rezaie, N. (2014). Contextual Factors and the Creativity of Employees: The Mediating Effects of Role Stress and Intrinsic Motivation on Economy and Finance Organization in Tehran. Journal of Resources Development and Management, 4(1)22-42.

Sapie, N. M., Hussain, M. Y., Awang, A. H., \& Ishak, S. (2015). Work Environment Determinants of Innovative Work Behaviour. Journal for Studies in Management and Planning, 1(5), 149-159.

Scott, S. G., \& Bruce, R. A. (1994). Determinants of innovative behave ior: A path model of individual innovation in the workplace. Academy of management Journal, 37(3), 580-607.

Shahin, A., \& Zeinali, Z. (2010). Developing a Matrix Framework for the Relationship between Organizational Learning and Innovativeness-With a Case Study in a Manufacturing Company. International Journal of Business and Management, 5(7), P187-203.

Thomas, Kenneth. (2002). Intrinsic motivation at work: Building energy and commitment. San Francisco: Berrett-Koehler Publishing.

Van de Ven, A. H. (1986). Central problems in the management of innovation. Management science, 32(5), 590-607.

Van Dijk, C., \& Van Den Ende, J. (2002). Suggestion systems: transferring employee creativity into practicable ideas. $R \& D$ Management, 32(5), 387-395.

Wang, C.-H., Chen, K.-Y. \& Chen, S.-C. (2012). Total quality management, market orientation and hotel performance: the moderating effects of external environmental factors. International Journal of Hospitality Management, 31(1)119-129.

Woodman, R. W., Sawyer, J. E., \& Griffin, R. W. (1993). Toward a theory of organizational creativity. Academy of management review, 18(2), 293-321.

Xerri, M., Brunetto, Y., \& Shacklock, K. (2009). The innovative behaviour of employees within a small to medium sized enterprise: a social capital perspective. Asia Pacific Journal of Human Resources, vol. 51, no. 1, pp. 103-123.

Yidong, T., \& Xinxin, L. (2013). How ethical leadership influence employees' innovative work behavior: A perspective of intrinsic motivation. Journal of Business Ethics, 116(2), 441-455. 
